\title{
Drying Kinetics and Moisture Diffusivity Study of Okro Slice
}

\author{
Olajire AS, Tunde-Akintunde TY and Ogunlakin GO*
}

Department of Food Science andEngineering, Ladoke Akintola University of Technology, Ogbomoso, Oyo State, Nigeria

\begin{abstract}
Okro (Abelmoschus esculentus L.) is abundant during the raining season in Nigeria. However, storage for the period of offseason is not commonly employed, because it is highly perishable resulting in huge post-harvest losses which lead to wastage. Drying as a form of pretreatment can reduce these post-harvest losses. This study investigates the drying kinetics and effect of slice thickness on drying of okro samples using oven $\left(40^{\circ} \mathrm{C}, 45^{\circ} \mathrm{C}\right.$ and $\left.50^{\circ} \mathrm{C}\right)$, sun and solar drying. Freshly harvested okro fruits were cut transversely into slices $(0.5 \mathrm{~cm}, 1.5 \mathrm{~cm}$ and $2.0 \mathrm{~cm})$ and dried using three different drying methods; sun, solar and oven at $40^{\circ} \mathrm{C}, 45^{\circ} \mathrm{C}$ and $50^{\circ} \mathrm{C}$. Drying characteristics (Effective Moisture Diffusivity (EMD) and Activation Energy (AE)) were determined. The EMD and EA for slice $0.5 \mathrm{~cm}, 1.5 \mathrm{~cm}$ and $2.0 \mathrm{~cm}$ were $\left(4.50-5.96 \times 10^{-10} \mathrm{~m}^{2} / \mathrm{s}\right.$ and $\left.12.90 \mathrm{kJmol}^{-1}\right) ;(0.32-$

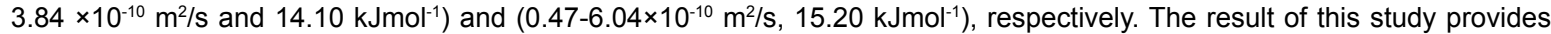
useful information for food processor on the drying of okro.
\end{abstract}

Keywords: Okro; Drying; Slice thickness; Moisture diffusivity; Activation energy

\section{Introduction}

Okro (Abelmoschus esculentus $L$.) is an annual vegetable crop that is grown for its fruits and seeds in tropical and subtropical regions. It is highly valued for its mature, tender green fruit which is a good source of fiber, minerals, and vitamins, including vitamin A, B complex and ascorbic acid [1]. Okro also contains a unique combination of valuable nutrients which are of beneficial to health. It is high in vitamin $\mathrm{B}_{6}$, fibre; calcium and folic acid which help prevent neural tube defects in developing foetuses [2]. The young fruits are consumed as cooked vegetables and in canned, frozen or dried forms. Despite its nutritional or health benefits, the high moisture content of okro makes it perishable [3]. Due to its high perishability, okro needs to be processed before storage to make it available throughout the year. The major unit operations used in processing okro include slicing, grating, crushing, pickling and drying [4]. Slicing, grating and crushing produces intermediate products that have low shelf lives thus making it inappropriate for long-term storage. Drying is one of the processing methods for obtaining products with increased shelf life [5].

Drying is one of the methods that can be used to reduce the moisture content present in highly perishable products, such as fruits and vegetables to a level where growth of microorganism will be inhibited. The method has been widely used to dry fruit and vegetable including red pepper [6]. Drying of biological materials is a complicated process which involves simultaneous mass and heat transfer phenomena that occur inside the material [7]. Drying of fruits and vegetables can be accomplished by several methods, including sun drying, hot air drying, vacuum drying, microwave drying, freeze drying and oven drying. The knowledge of effective moisture diffusivity of a crop which is necessary for designing the mass transfer process and the activation energy which describes the relative ease of moisture migration with the product is important for optimisation of the drying process [8]

Several works have been conducted on the effect of drying condition on the drying kinetics of fruit and vegetable [9-12]. Considering the past works on drying kinetics of okro, low temperatures have not been used as this will reduce the degradation of the physical and nutritional qualities of okro $[13,14]$. This study was therefore to determine the drying characteristics of okro using different drying methods (oven, sun, solar) as affected by slice thickness; and to also determine the effective moisture diffusivity and activation energy

\section{Materials and Methods}

\section{Materials}

Freshly harvested okro was obtained from Teaching and Research Farm, Ladoke Akintola University of Technology (LAUTECH), Ogbomoso, Oyo State. The fruits were deep green with elongated pointed edges, with approximate lengths of $7 \mathrm{~cm}$ and diameters of $1.8 \mathrm{~cm}$.

\section{Preparation and drying procedure of okro sample}

The okro was sorted to remove impurities and rotting fruits before it was cut into slices of $0.5 \mathrm{~cm}, 1.5 \mathrm{~cm}$ and $2.0 \mathrm{~cm}$ thickness. The sliced okro samples were dried using three drying methods namely; oven (at $40^{\circ} \mathrm{C}, 45^{\circ} \mathrm{C}$ and $50^{\circ} \mathrm{C}$ ), sun and solar drying methods. An oven dryer (Gallenkamp BS oven, UK) situated at the Food Science and Engineering Laboratory in LAUTECH was used. Sliced okro samples of $400 \mathrm{~g}$ were spread out in drying trays of dimensions $42 \mathrm{~cm}$ by $27 \mathrm{~cm}$ and placed in the oven at a temperature of $40^{\circ} \mathrm{C}$. Reading was taking at an interval of $30 \mathrm{~min}$ until constant weight was obtained i.e. the weight of three consecutive reading is constant. The experiment was repeated for temperatures of $45^{\circ} \mathrm{C}$ and $50^{\circ} \mathrm{C}$. For solar drying, sliced samples (400 g each) of thicknesses $0.5 \mathrm{~cm}, 1.5 \mathrm{~cm}$ and $2.0 \mathrm{~cm}$ were separately spread on well labeled drying trays and placed inside the solar dryer that has been placed directly in the sun. The duration of the drying was from 8 am- 6 pm daily which represent the sunlight hours [15]. The samples were weighed every hour until three consecutive readings were constant. For sun drying, sliced samples (400 g each) of thicknesses $0.5 \mathrm{~cm}, 1.5 \mathrm{~cm}$ and $2.0 \mathrm{~cm}$ were thinly spread on well labeled drying trays and placed directly under the sun. The duration of the drying was

*Corresponding author: Ogunlakin GO, Department of Food Science and Engineering, Ladoke Akintola University of Technology, Ogbomoso, Oyo State, Nigeria, Tel: +2348038309212; E-mail: googunlakin@lautech.edu.ng

Received July 09, 2018; Accepted August 30, 2018; Published September 03 2018

Citation: Olajire AS, Tunde-Akintunde TY, Ogunlakin GO (2018) Drying Kinetics and Moisture Diffusivity Study of Okro Slice. J Food Process Technol 9: 751. doi: 10.4172/2157-7110.1000751

Copyright: @ 2018 Olajire AS, et al. This is an open-access article distributed under the terms of the Creative Commons Attribution License, which permits unrestricted use, distribution, and reproduction in any medium, provided the original author and source are credited. 
also between 8 am- 6 pm daily (which represent the drying hour). The weights of the samples were measured hourly and the drying continued until three consecutive readings were constant.

\section{Drying kinetics}

Moisture content: The initial moisture content of okro before drying which was $0.81 \%$ was determined using AOAC [16]. Since the determination of drying kinetics is based on the moisture content, the weight of okro during drying was converted to moisture content using Equation 1.

$$
M C=\frac{w_{i}-w_{d}}{w_{i}} \times 100
$$

where, $\mathrm{MC}$ is the moisture content, $\mathrm{w}_{\mathrm{i}}$ is the initial mass of the sample before drying and $\mathrm{w}_{\mathrm{d}}$ is the mass of the sample at time $\mathrm{t}$.

Moisture ratio: The moisture ratio during drying experiment was obtained by using Equation 2

$$
M R=\frac{M-M e}{M i-M e}
$$

where, $\mathrm{MR}$ is the dimensionless moisture ratio, $\mathrm{M}, \mathrm{Me}$ and $\mathrm{Mi}$ is the moisture content at any time $t$, equilibrium moisture content and initial moisture content respectively. However, the moisture ratio (MR) was simplified to $\mathrm{M} / \mathrm{Mi}$ instead of $(\mathrm{M}-\mathrm{Me}) /(\mathrm{Mi}-\mathrm{Me})$ because of the relative humidity of the drying air continuously fluctuated during open sun and solar drying processes [17]. Hence, moisture ratio was calculated as:

$$
M R=\frac{M}{M_{i}}
$$

Effective moisture diffusivity, activation energy: Effective moisture diffusivity $\left(\mathrm{D}_{\text {eff }}\right)$ was calculated using Fick's second equation of diffusion as reported by Aremu et al. [18], considering constant moisture diffusivity, infinite slab geometry, and a uniform initial moisture distribution.

$$
M R=\frac{8}{\pi^{2}} \exp \left(-\frac{\pi^{2} D_{E f f}}{4 L^{2}} t\right)
$$

where, $\mathrm{MR}$ is the moisture ratio, $\mathrm{D}\left(\mathrm{m}^{2} \mathrm{~s}^{-1}\right)$ is the effective moisture diffusivity, $\mathrm{L}(\mathrm{m})$ is the sample thickness and $\mathrm{t}$ is the drying time (s).

Equation 4 which involved a series of exponents can be simplified to Equation 5

$$
\text { Therefore, } \operatorname{InMR}=\frac{-\pi^{2} D_{\text {eff }}}{4 L^{2}} t+\frac{\operatorname{In} 8}{\pi^{2}}
$$

The effective diffusivity $\left(\mathrm{D}_{\text {eff }}\right)$ at each temperature was obtained from the slope of the plot of $\ln (\mathrm{MR})$ against time for each corresponding temperature data.

Activation energy was calculated by using an Arrhenius equation [19]. Ojediran and Raji [20] also reported that diffusivity coefficient for castor seeds at different temperatures was found to be well predicted by Arrhenius equation.

$$
D_{e f f}=D_{0} e^{-\frac{E_{a}}{R_{g}(T+27315)}}
$$

where, $\mathrm{D}_{\mathrm{o}}$ is the maximum diffusion co-efficient, $\mathrm{Ea}$ is the activation energy $\left(\mathrm{kJmol}^{-1}\right), \mathrm{T}$ is temperature $\left({ }^{\circ} \mathrm{C}\right)$ and $\mathrm{Rg}$ is the gas constant.

$$
\ln D_{e f f}=\left[-\frac{1}{\operatorname{Rg}(T+273.15)}\right] E_{a}+\ln D_{0}
$$

In the same manner to $\mathrm{D}_{\text {eff }}$, the Activation energy was obtained as the slope of the $\ln \mathrm{D}_{\text {eff }}$ against $-\frac{1}{\operatorname{Rg}(T+273.15)}$

\section{Result and Discussion}

\section{Determination of drying curve and drying rate curve}

The plots of moisture content against time which gave the drying curves for okro samples using different drying methods (oven (at $40^{\circ} \mathrm{C}$, $45^{\circ} \mathrm{C}$ and $50^{\circ} \mathrm{C}$ ), sun and solar) are as shown in Figures 1a-e while a plot of drying rate against average moisture content gave the drying rate curves as shown in Figures 2a-e.

At a drying temperature of $40^{\circ} \mathrm{C}$, equilibrium moisture content was reached in $930 \mathrm{~min}$ for okro slices of $2.0 \mathrm{~cm}$ thickness, $840 \mathrm{~min}$ for slice thickness of $1.5 \mathrm{~cm}$ and $600 \mathrm{~min}$ for slice thickness of $0.5 \mathrm{~cm}$. At a temperature of $45^{\circ} \mathrm{C}$, drying of slice thicknesses of $2.0,1.5$ and $0.5 \mathrm{~cm}$ took $900 \mathrm{~min}, 780$ and $570 \mathrm{~min}$ respectively. Lastly, it took 480, 420 and $330 \mathrm{~min}$ for slice thicknesses of $2.0,1.5$ and $0.5 \mathrm{~cm}$ respectively to reach the final weight at a temperature of $50^{\circ} \mathrm{C}$. A reduction in moisture content was observed for okro from mean value of $88.38 \mathrm{~g}$ water/g material to $0.15,0.15$ and $0.13,6.15,2.16 \mathrm{~g}$ water/g material for oven at temperature of 40 Postharvest treatments to control physiological and pathological disorders in lemon fruit, $45^{\circ} \mathrm{C}$ and $50^{\circ} \mathrm{C}$, sun and solar drying methods, respectively. A gradual decrease in moisture content with increase in drying time is observed, with the drying curve exhibiting a gentle downward curve. It was observed that the highest loss of moisture was at the early period of drying for the drying methods, this was as a result of the evaporation of free water in okro samples. The reduction in moisture content slowed down in the latter drying periods. This indicates that the free water has been evaporated leaving the bound water. This result was in line with the observation of Kabiru et al. [21] during the drying of mango slice, Islam et al. [22] during the drying of green banana, Lipaiboon [23] during the drying of pumpkin slice and Abano [24] during the drying of tomato slice. The drying time for samples that were oven dried was shorter than that of all other drying methods, this is because the drying temperatures for oven drying were higher than other drying methods. This result was in line with the observation of Bhosale and Arya [25], for drying okro using sun and solar dryer.

The effect of slice thickness on the drying of okro samples was that smaller slice thicknesses dried faster than the bigger slice thickness as presented in Figures 1a-e. This is because for smaller slice thickness the distance that the water molecule will travel from the core to the outer layer where evaporation will take place was shorter compared to larger slice thicknesses. This implied that drying at smaller slice thickness helps in reducing the drying time which may reduce the cost of drying. It was also observed from drying rate curves that the drying rate was higher at the beginning of drying when the moisture content of okro was the highest. The drying rate however decreased as drying progressed as shown in Figures 2a-e. This is due to the fact that as drying progresses, free water is evaporated, and bound water which remains is more difficult to evaporate which reduce that rate at which water is evaporated from the surface of the food material. The drying rate also increased with increase in drying air temperature which agreed with the findings of Ndukwu [26] in the drying of cocoa bean. This is because higher air temperatures resulted in greater diffusion of water which increases the rate at which water is evaporated from the surface of the okro samples.

\section{Effective moisture diffusivity $\left(\mathrm{D}_{\text {eff }}\right)$ and activation energy}

The $\mathrm{D}_{\text {eff }}$ values were obtained from the slope of the linear graph of lnMR against time from Figures 3a-e using Equation 6. The values of $\mathrm{D}_{\text {eff }}$ for the drying of okro are shown in Table 1 . It was observed 


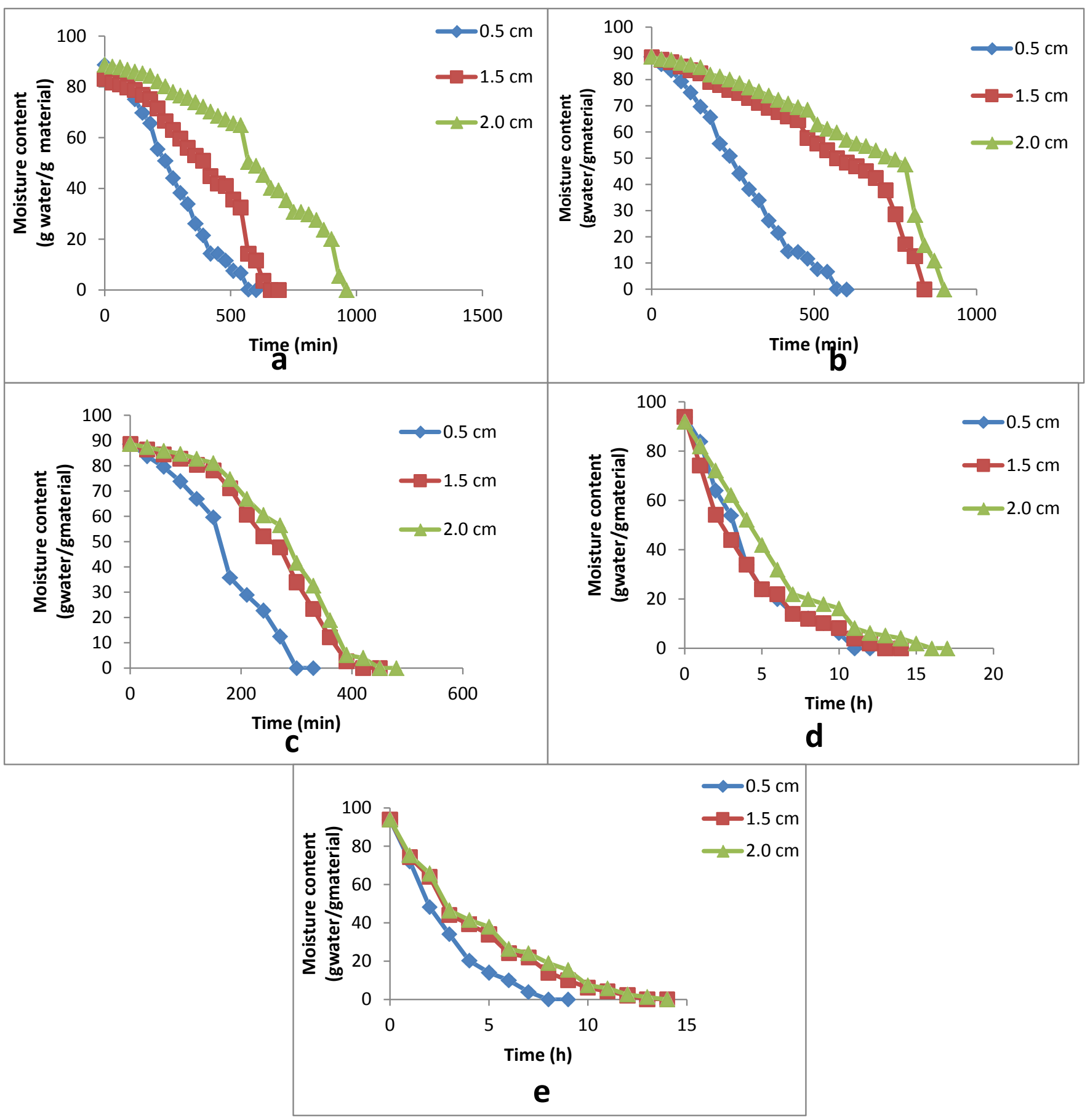

Figure 1: Drying curve at difference slice thickness dried with oven at (a) $40^{\circ} \mathrm{C}$, (b) $45^{\circ} \mathrm{C}$ and (c) $50^{\circ} \mathrm{C}$, (d) sun and (e) solar drying method.

that $\mathrm{D}_{\text {eff }}$ increased with increase in temperature. This was in line with the report of Aremu et al. [18] that $\mathrm{D}_{\text {eff }}$ increased with increase in temperature from $60^{\circ} \mathrm{C}$ to $80^{\circ} \mathrm{C}$ for slice thickness of $3 \mathrm{~mm}$ during the drying of mango. This was as a result of the fact that water diffusion which is mainly due to mass transport mechanism from the first phase of drying, as reported by Ojediran and Raji [20], increases with an increase in drying temperature. Moisture movement in the falling rate drying period where most of the drying took place was majorly by moisture diffusion. The activation energy for oven drying of okro, $12.90,14.10$ and $15.20 \mathrm{kJmol}^{-1}$ for slice thickness of $0.5 \mathrm{~cm}, 1.5 \mathrm{~cm}$ and $2.0 \mathrm{~cm}$, respectively was obtained from the slopes of linear plot in Figures $4 \mathrm{a}-\mathrm{c}$ according to Equation 7. Activation energy is needed to initiate the moisture diffusion within the slice and is a function of temperature sensitivity. From the result obtained, as slice thickness 

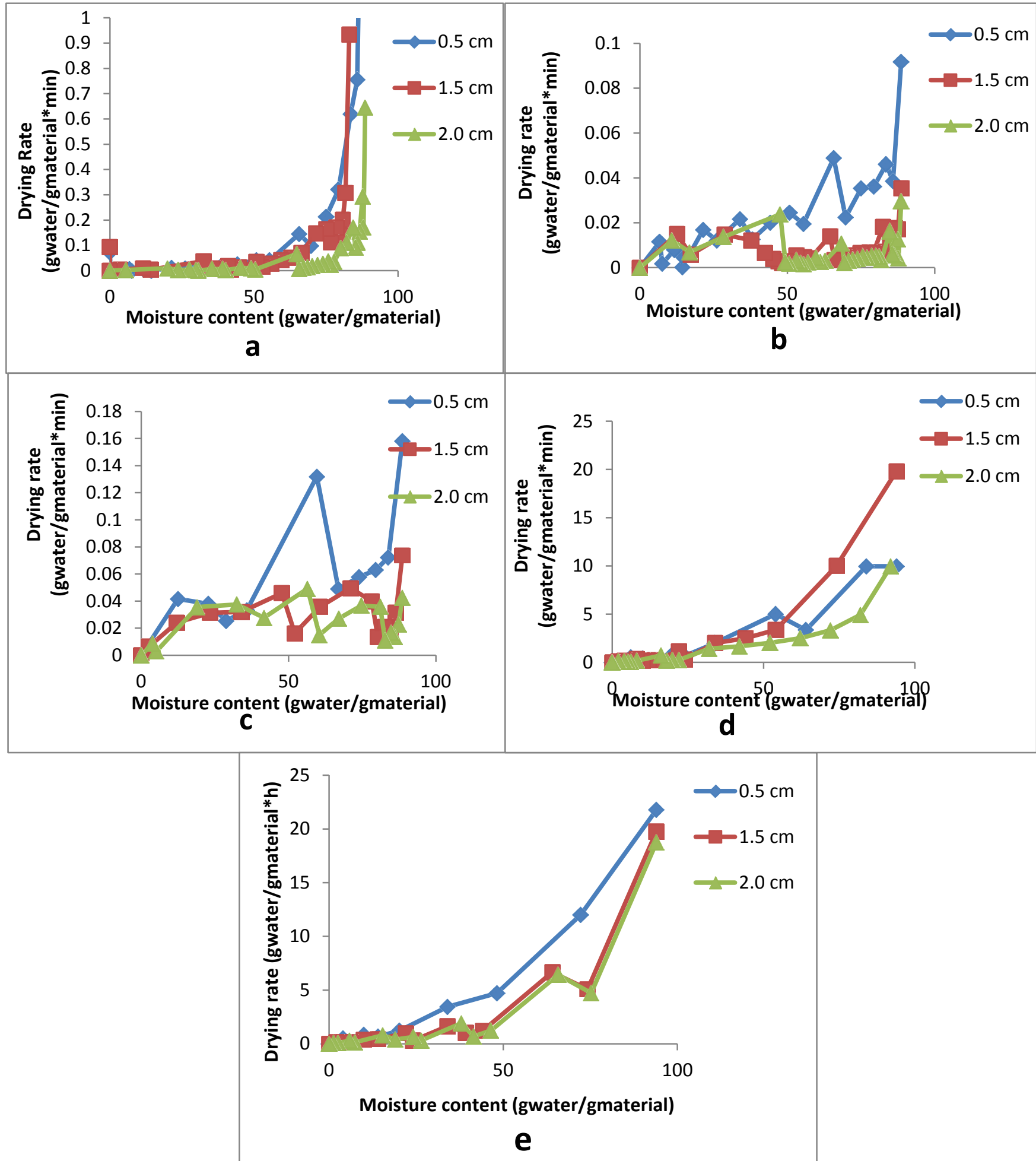

Figure 2: Drying rate curve at difference slice thickness dried with oven at (a) $40^{\circ} \mathrm{C}$, (b) $45^{\circ} \mathrm{C}$ and (c) $50^{\circ} \mathrm{C}$, (d) sun and (e) solar drying methods.

increased activation energy that is needed to drive moisture out of the slice increased. Slice thickness of $2.0 \mathrm{~cm}$ will required more activation energy for effective drying. Therefore, it is better to operate at lower slice thickness so as to reduce the activation energy and to save time and energy consumption. 
Citation: Olajire AS, Tunde-Akintunde TY, Ogunlakin GO (2018) Drying Kinetics and Moisture Diffusivity Study of Okro Slice. J Food Process Technol 9: 751. doi: 10.4172/2157-7110.1000751

Page 5 of 7

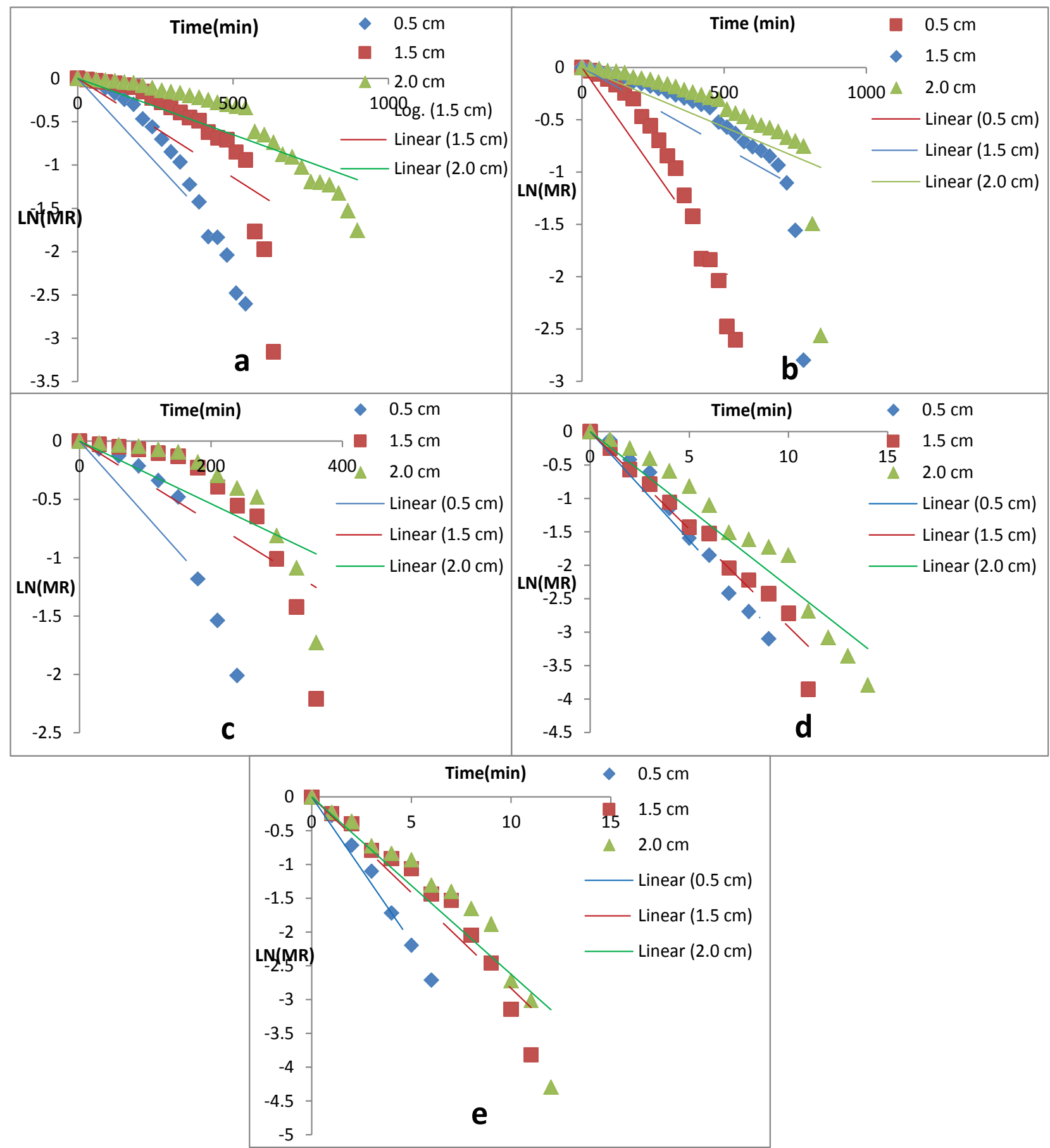

Figure 3: Estimation of moisture diffusivity at difference slice thickness dried with oven $\left(40^{\circ} \mathrm{C}, 45^{\circ} \mathrm{C}\right.$ and $\left.50^{\circ} \mathrm{C}\right)$, sun and solar drying methods.

\begin{tabular}{|c|c|c|c|c|}
\hline \multirow{2}{*}{ Slice thickness $(\mathrm{cm})$} & \multicolumn{3}{|c|}{ Effective Moisture Diffusivity $\left(\mathrm{m}^{2} / \mathrm{s}\right)$} \\
\cline { 2 - 5 } & $40^{\circ} \mathrm{C}$ & $45^{\circ} \mathrm{C}$ & \multicolumn{2}{|c|}{5} \\
\hline 0.5 & $4.50 \times 10^{-10}$ & $4.60 \times 10^{-10} \mathrm{C}$ & $2.00 \times 10^{-10}$ & $5.96 \times 10^{-10}$ \\
\hline 1.5 & $3.18 \times 10^{-115}$ & $2.74 \times 10^{-10}$ & $3.84 \times 10^{-10}$ & $1.61 \times 10^{-10}$ \\
\hline 2.0 & $4.68 \times 10^{-11}$ & $4.48 \times 10^{-10}$ & $6.04 \times 10^{-10}$ & $2.63 \times 10^{-10}$ \\
\hline
\end{tabular}

Table 1: Effective moisture diffusivity $\left(\mathrm{m}^{2} / \mathrm{s}\right)$ of the different drying processes of okro. 
Citation: Olajire AS, Tunde-Akintunde TY, Ogunlakin GO (2018) Drying Kinetics and Moisture Diffusivity Study of Okro Slice. J Food Process Technol 9: 751 . doi: $10.4172 / 2157-7110.1000751$
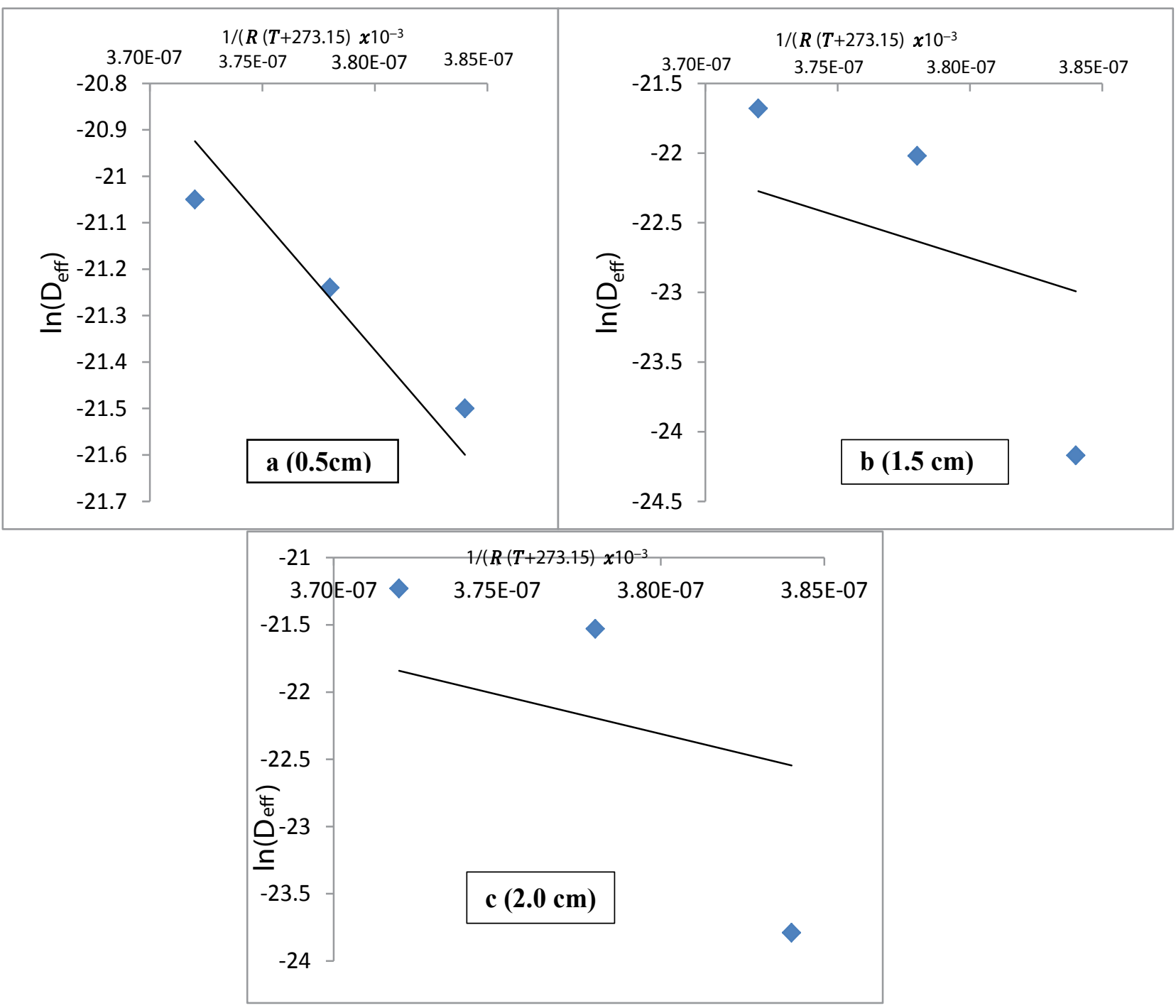

Figure 4: Graph of $\ln \left(D_{\text {eff }}\right)$ against $\frac{1}{R(T+273.15)} \chi 10^{-3}$ for difference slice thickness.

\section{Conclusion}

Drying of okro is done to ensure that the fruit is available throughout the year. The knowledge of the drying characteristics of the process is essential in the optimisation of the process. Drying characteristics considered were namely drying rate, effective moisture diffusivity and activation energy. The drying rate reduced as drying progressed and increased with increase in drying temperature. The lowest effective moisture diffusivity was obtained in sun dried samples while the highest effective moisture diffusivity was obtained in samples dried at $50^{\circ} \mathrm{C}$ and the activation energy for drying of okra was $12.90 \mathrm{kJmol}^{-1}$.

\section{References}

1. Siemonsma KO (1982) Nutritional quality and health benefit of okro (Abemoschus Esculentus). J Med Res 14: 70-81.

2. United State Department of Agriculture (2005) National nutrient data base, food technology factsheet. Longman USA.
3. Vegetable Crop and Research Programme (1996) United State Department of Agriculture, Ministry of Agriculture, Food and Fisheries, USA.

4. Farinde A, Owolarafe O, Ogungbemi I (2007) An overview of production, processing, marketing and utilisation of okro in Egbedore Local Government Area of Osun State, Nigeria. J Agric Eng 4: 1-17.

5. Singh RP, Dennis RH (2009) Introduction to Food Engineering. (4 ${ }^{\text {th }}$ edtn), Elsivier.

6. Maskan M (2001) Kinetics of colour change of kiwifruits during hot air and microwave drying. J Food Eng 48: 169-175.

7. Yilbas BS, Hussain MM, Dancer I (2003) Heat and moisture diffusion in slab products to convective boundary condition. J Heat Mass Transfer 39: 471- 476.

8. Chien HC, Chung LL, Michael C, Ching LH, Lugman CA (2008) Drying kinetics and product quality of dried chempedak. J Food Eng 88: 522-527.

9. Famurewa JAV, Olumofin KM (2015) Drying kinetics and influence on the chemical characteristics of hydrated okro (Abelmoschus esculentus) using cabinet dryer. J Eng Technol 3: 7-19. 
Citation: Olajire AS, Tunde-Akintunde TY, Ogunlakin GO (2018) Drying Kinetics and Moisture Diffusivity Study of Okro Slice. J Food Process Technol 9: 751. doi: 10.4172/2157-7110.1000751

Page 7 of 7

10. Wankhade PK, Saplid VS (2013) Drying characteristics of okro slices using different drying Method by conparative evaluation. J Eng Comp Sci 2: 40-45.

11. Yılmaz FM, Yuksekkaya S, Vardin H, Karaaslan M (2017) The effects of drying conditions on moisture transfer and quality of pomegranate fruit leather (pestil). J Saudi Society Agric Sci 16: 33-40.

12. Izli N, Izli G, Taskin O (2017) Influence of different drying techniques on drying parameters of mango. Food Sci Technol Campinas 37: 604-612.

13. Vikram VB, Ramesh MN, Prapull SG (2005) Thermal degradation kinetics of nutrients in orange juice heated by electromagnetic and conventional methods. J Food Eng 69: 31- 40.

14. Aamir M, Boonsupthip W (2017) Effect of microwave drying on quality kinetics of okra. J Food Sci Technol, 54: 1239-1247.

15. Krutman A (1981) Development of alternative dehydration methods for okro. Sci J 42: 551.

16. AOAC (2005) Official method of analysis. Association of Official Analytical Chemists, Maryland, USA.

17. Menges HO, Ertekin C (2006) Mathematical modeling of thin-layer drying of golden apples. J Food Eng 77: 119-125.

18. Aremu AK, Adedokun AJ, Abduganiyu OR (2013) Effect of slice thickness and temperature on the drying kinetics of mango. Agric Eng J 15: 41-50.
19. Aghbashlo MK, Arabhosseini MH, Nazghelichi T (2008) Modelling the carrot thinlayer drying in a semi-industrial continuous bed dryer. J Food Sci 29: 528-538.

20. Ojediran JO, Raji AO (2011) Thin-layer drying characteristic of castor (Ricinus Communis) seed. J Food Proc Preserv 35: 647- 655.

21. Kabiru AA, Joshua AA, Raji AO (2013) Effect of slice thickness and temperature on the drying kinetics of mango (Mangifera indica). Int J Res Rev Appl Scs 15 : 41- 50.

22. Islam MS, Haque MA, Islam MN (2012) Effect of drying parameter on dehydration of green banana (Musa sepientem) and its use in potato (Solanum tuberosum) chips formulation. The Agriculturists 10: 87-97.

23. Limpaiboon $K$ (2011) Effect of temperature and slice thickness on drying kinetics of pumkin slices. Walailak J Sci Technol 8: 159- 166.

24. Abano EE, Ma H, Qu W (2011) Influence of air temperature on the drying kinetics and quality of tomato slices. J Food Proc Technol 2: 1-9.

25. Bhosale SS, Arya AB (2004) Effect of different modes of drying on moisture content and drying time of selected vegetable. Ind J Food Eng 63: 349-359.

26. Ndukwu MC (2009) Effect of air temperature and drying air velocity on the drying rate and drying constant of coca beans. Agric Eng Int CIGR J 1091: 23-30. 